\title{
SCRAPIE: A TRANSMISSIBLE AND HEREDITARY DISEASE OF SHEEP
}

\author{
H. B. PARRY \\ Nuffield Institute for Medical Research, University of Oxford
}

\section{INTRODUCTION}

Received 22.vii.6s

SGRAPIE is a chronic, wasting disease of sheep known in Britain and Western Europe since $177^{2}$ (Comber, I 772) and probably since I 720 (see M'Gowan, 1914). It is always fatal and has from time to time been responsible for the elimination of the sheep population of a district. It has recently been recognised in North America and the Antipodes.

The cause of scrapie has been for long a matter of dispute. In the eighteenth and early nineteenth centuries many writers considered scrapie to be hereditary, but during the past half century the view that it was a naturally infectious disease has gained ground, supported since 1936 by studies of experimental transmission by inoculation.

Precise knowledge of the natural disease has been difficult to assemble. The sheep-owners are reticent, clinical manifestations vary considerably, no simple laboratory tests are known and the pathologic lesions, often inconspicuous, have been considered non-specific. However, recent work (Beck, Daniel and Parry, 1961) has shown that there are specific degenerative changes in the brain in the hypothalamic-hypophyseal system and in the olivo-ponto-cerebellar system.

Data have been collected relating to 1200 cases of which over I ooo have detailed individual records. They provide evidence of 3 kinds; first, that the prime cause of scrapie is heredity and that only individuals of the homozygous recessive type (ss as opposed to $s S$ and $S S$ ) manifest the disease; second, that affected animals harbour a substance, the transmissible scrapie agent, which is infectious artificially, and third, that scrapie is not naturally infectious (Parry, 1960).

\section{CRITERIA OF THE DISEASE}

\section{(i) Clinical signs}

The various clinical forms of scrapie have been discussed by Bosanquet, Daniel and Parry (1956) and Parry (1957); only cases of their Group A syndromes, which comprise more than 95 per cent. of all cases, have been accepted.

In these syndromes rubbing of the buttocks, flanks and head is conspicuous and may be almost continuous in some advanced cases; 
in others nibbling of the haired skin of the lower legs is marked, while nearly all animals exhibit a pronounced nibbling reflex on deep palpation of the soft tissues of the back. In many an acneform papular rash appears on the haired portions of the skin, notably of the lower legs and nose, and hæmatomata of the ears are common.

Nearly all cases show early fatigue with moderate exercise and in some this asthenia progresses rapidly to general weakness with inability to rise. Progressive loss of bodily condition leading to emaciation, in spite of a food intake adequate to maintain body weight, is conspicuous in the majority of cases; a few increase in weight and die obese. Excessive thirst is not infrequent.

Many show disturbances of gait, notably of the hindlimbs, which are wide-based, and a high stepping movement of the forelimbs may occur ("Traberkrankeit" of German writers); if the ataxia is severe, the animals reel like a drunken human. In some cases there is in addition a disturbance of postural fixation leading to a coarse tremor or trembling (" Tremblante " of French writers), which is accentuated by excitement. The body-righting reflexes are unaffected until an advanced stage. Tendon reflexes are normal or even exaggerated, and the normal response to pin-prick is very rarely absent.

Mental disorder leading to behavioural and personality changes and even dementia occurs frequently. Many become uncooperative and refuse to be driven; some become fearless of humans and dogs while others become very excitable and are extremely distressed by any handling or change in their daily routine. Not infrequently a minor behavioural abnormality may be the first sign noted. Blindness occurs in some 5 per cent. of cases.

Body temperature and heart rate show unusual fluctuations although within normal limits, but the cardiovascular system is generally unstable. Advanced cases are particularly susceptible to cold and wet.

The disease is almost always slowly progressive with death in 6 weeks to 6 months, rarely a year. Very occasionally complete remission of signs occurs. Three such cases, two rams and a ewe have been seen, but they have all died of scrapie, the longest intermission being $3 \frac{1}{2}$ years from the age of $2 \frac{3}{4}$.

In flocks with a high presumptive frequency of the scrapie gene, unusual syndromes of palsy, wasting and myasthenia of uncertain ætiology occur alongside cases generally accepted as scrapie, with which they appear to be closely associated.

At autopsy few macroscopic abnormalities are present. Conspicuous myopathic lesions seen in the early cases of the series have been absent in many recent cases, although a high proportion of animals show some abnormality of the skeletal musculature. The adrenal glands are usually enlarged and the thyroid glands small. The central nervous system shows the specific changes noted above (Beck, Daniel and Parry, r96r). 


\section{(ii) Diagnosis}

The diagnosis has been based on the following criteria: (I) unequivocal clinical signs; (2) a fatal outcome in all animals retained under observation; (3) some lesions in the skeletal muscles and changes in the endocrine glands; (4) cytoplasmic vacuolation and neuronal degeneration in the nervous system; (5) the demonstration of a transmissible agent in the brain.

It has not been practicable to apply all these criteria except in a few cases. Of the 1200 animals affected, 500 have been seen by the author, while in the remainder, the diagnosis has been based on the clinical observation of others with experience of the disease. Some errors of diagnosis will have occutred, but their number is probably small, since all cases have been discussed with the observer within 1-2 months, occasionally up to 6 months, of the illness occurring, and any case in which the evidence was unconvincing has been excluded. The first cases in any flock and doubtful cases have been examined personally. All the cases examined fully have conformed to the above criteria.

\section{SOURCE OF MATERIAL}

The principal data have been collected over the years 1952-6o from a group of some $5^{\circ}$ recorded pedigree sheep flocks of ro breeds, with over 8500 breeding females in 1960 ; more than 20 , 000 animals have been under observation during the period. The flocks are dispersed in 17 counties of England and Scotland on varied soil types; they have a very high standard of shepherding, and are members of a Stud Sheep Health and Improvement Scheme, known as the Oxford Scheme (Parry, 1957).

Additional data have been obtained from other commercial flocks in which individual animals are not recorded. The Oxford Scheme flocks are visited at least twice a year, and their records are supervised closely. In these flocks individual animals are identificd by one and usually two independent methods of permanent identification in addition to temporary fleece numbers and marks; records are kept of individual matings, births, markings and all cases of ill health, death and disposal. These records cover all the stud rams and breeding females, but only a small proportion of their progeny, namely the females retained in the flock; these represent usually 20-25 per cent. of the females born, and are selected when $1 \frac{1}{2}$ years old, partly on inspection for the main breed points and partly on the performance records of their relatives. The males and surplus young females are sold before they are 2 years old and only occasionally is it possible to follow their subsequent history. Older females may be removed from the flock at any time if they fail to perform satisfactorily or suffer some acquired disablement, although good breeding animals are kept until they have had 5 or more gestations and are 7-10 years old.

These flocks normally breed all their own females but purchase stud rams from other flocks in the Oxford Scheme. The rams are selected mostly when 6-8 months old for good growth and muscular development with satisfactory wool and breed conformation. They are first used as sires when about 8 months old and kept for 2 or 3 years, occasionally until 6 or 7 years old, mating ro-4o females each year. As these flocks comprise the principal ram-producing flocks of their breeds, the stud rams tend to have a number of common ancestors, which have been outstandingly successful sires in their breeds ; thus many rams will have at least one greatgrandparent in common. There is therefore a tendency to a concentration of 
certain lines in each breed, and for a high degree of consanguinity to be prevalent. Each flock-group is virtually a closed breeding population, a matrilinear breeding group, with a relatively high index of inbreeding and extreme polygamy.

These flocks are free from the common infectious diseases, except contagious pustular dermatitis. Stillbirths and other neonatal mortalities are unexceptional and severe congenital anomalies rare, being less than 5 per 10,000 lambs born. There have been no reasons to suspect fotal death early in gestation other than on odd occasions. The general health record of these flocks is high; the annual loss of breeding ewes from all causes other than scrapie is less than 5 per cent.; the percentage of ewes pregnant more than 95 and only sporadic abortions not associated with infections have been observed. The average litter size is $1 \cdot 6-1 \cdot 8$ and the reared lamb ratio $1 \cdot 4^{-1} \cdot 5$ lambs per ewe put to service.

For many years some flockmasters have endeavoured to dispose of (i.e. cull) any near relatives of sheep showing signs of scrapie or suspected of being affected. Since 1952 the majority of full and half brothers and sisters, daughters, sons, mothers and fathers of affected animals have been culled but no attempt has been made to quarantine affected sheep; they have remained in the main flock until it was convenient to dispose of them.

This general information relating to groups of the principal flocks of the breeds has been supplemented by a more detailed study of several flocks with good records, especially flock A, for which exceptional records are available for over 20 years. This flock has been self-contained for females since 1940. There has been one shepherd who has kept a notebook for each lambing season in which the tupping groups and other details were noted. As each ewe lambed, the date, her health, milk flow and particulars of parturition were noted, together with the number, sex and condition of the lambs, their sire, and a diagram of the ear marks inserted. These notebooks are available from 1939. From 1940 onwards a standard method of marking all sheep by a system of numbering by ear-notching carried out in the lambing coops within 2-3 days of birth, followed before they were 18 months old by tattooing a year letter with the ear notch number into one ear and the breed emblem and registered number of the flock into the other ear. Latterly each breeding ewe has had a fleece number branded on her side, so that she may be readily identified without the necessity of examining the ear marks closely. From these notebooks it has been possible to compile a comprehensive record of the flock with exceptionally few discrepancies, for when a mating has been in doubt this has been recorded. The shepherd had kept a list of all cases of scrapie since the first one was noted in 1945, while since 1952 nearly every case had been examined clinically by the author and has been kept in hospital under observation; and latterly, all have been examined at autopsy. Similar records are available for flock B, but not all the early cases of scrapie were recorded.

As public knowledge of the occurrence of scrapie in a flock may have serious financial and social consequences for both flockmaster and shepherd, the data to be presented are given in a form which is designed to obscure their precise origin.

\section{INCIDENCE}

\section{(i) Terminology}

The birth-group comprises all animals born into a flock in one breeding season, usually of $\mathrm{I} 2$ months; in sheep breeding twice a year the period is 6 months.

The age-group includes all animals of a given age, normally covering one year, and commencing when an animal is 6 months old, e.g. an 
animal between 6 and 18 months of age is in the one-year-old agegroup.

The attack-rate is the number of manifest cases of scrapie per Ioo breeding ewes occurring in a breeding year. The incidence, expressed as a similar percentage, is a less precise term used to describe the approximate manifestation over a period of years.

A flock or flock-group is considered to be free if over 5 years or more no manifest case has been observed in the home sheep and no case in sold sheep has come to notice. If affected, a sporadic incidence is $<\mathrm{I}$ per cent, a low incidence I-3 per cent., a medium incidence 4-10 per cent., a high incidence io per cent. and above.

\section{(ii) Generol}

Four flock-groups, 3 pure-bred and I cross-bred, have adequate and supervised records for 5 years or longer; one of these groups is free of scrapie; 2 of the affected flock-groups have a low to medium incidence, while in the third it is sporadic. Five other flock-groups with good records, but not yet supervised for 5 years, are probably free. Thus the incidence varies very much between different flockgroups, although direct and indirect contact between animals from affected and unaffected flock-groups occurs frequently at agricultural shows and on certain farms. It occurs in pure-bred and cross-bred sheep, of long- and short-wooled breeds, on mountain and lowland.

\section{(iii) By flocks and flock-groups}

Of I 2 free flocks, 9 have used many rams from flocks with affected animals during the period of the rams' breeding and rearing, while in 2 flocks stud rams have manifested scrapie at or shortly after the mating period without any further case developing in 3 and 5 years respectively. In 9 flocks an occasional case has occurred giving a sporadic incidence, often with periods of several years without a case.

Among the initial high incidence flocks the attack-rate has declined in three from 8.6 to $I .8$ per cent., while in two, in which several stud rams used extensively were subsequently affected, it has remained about Io per cent. In one flock thought to be free an attack rate of 15 per cent. appeared suddenly in females of certain families, but suspected cases in sold sheep had been reported for several years.

The striking feature is the wide fluctuations in the attack-rate in different flocks over a period of years and even from year to year, the disease becoming absent and then reappearing in a capricious manner, the flock meanwhile being exposed to apparently similar environmental factors. Many flocks remain free in spite of using rams from affected flocks. In some an occasional sporadic case occurs, but the disease does not spread; in others with no recorded cases for years the disease may appear suddenly as an epidemic. 


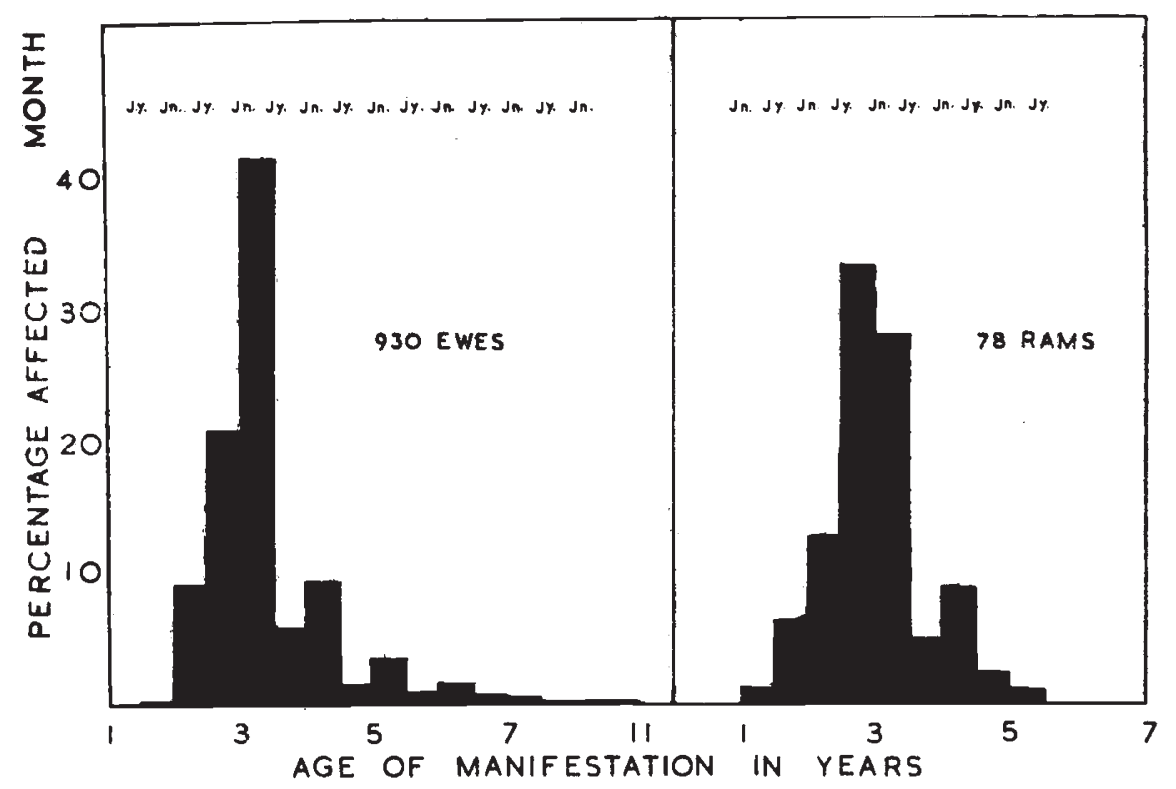

FIG. I.-The age, in six-month periods, at which unequivocal clinical signs of scrapie were first manifest in 1008 sheep.

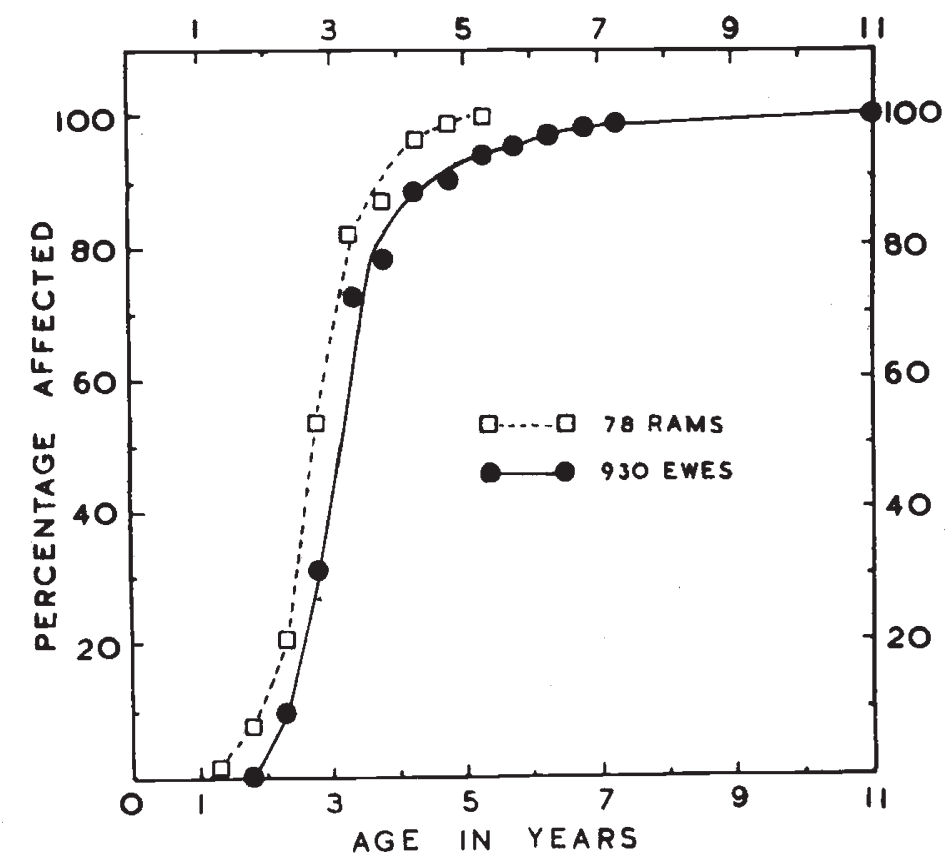

Fig. 2.-Curves showing the cumulative manifestation for rams and ewes based on the percentage of all animals of each sex affected by a given age. 


\section{(iv) By age of individuals}

Adequate records are available for 1008 affected animals, 930 ewes and 78 rams. The small number of rams recorded is due to the small sample under observation; only one ram is retained for every 2040 females and until recently the majority of stud rams have been disposed of before 3 years of age.

The age of onset of unequivocal signs were classified by half-yearly intervals. The results are shown in figs. I and 2, which demonstrate that the great majority of cases manifest between 2 and 7 years of age.

TABI.E I

The age of manifestation, expressed as the percentage of those affected, in the total sample $A$, in the preliminary sample $B\left(1945^{-5} 8\right)$, and in the current sample $C\left(195^{8-60)}\right.$. Sample $D$ contains those individuals from samples $B$ and $C$ which were the progeny of two affected parents, and all of whom are expected to manifest (see table 3)

\begin{tabular}{|c|c|c|c|c|c|c|c|c|c|c|}
\hline \multirow{2}{*}{ Sample } & \multirow{2}{*}{$\begin{array}{c}\text { No. of } \\
\text { animals }\end{array}$} & \multicolumn{9}{|c|}{ Percentage of the sample manifesting at this age in years } \\
\hline & & $\frac{1}{2}-1 \frac{1}{2}$ & $1 !-2 !$ & $2 \frac{d}{2}-3 \frac{1}{2}$ & $3 \frac{1}{2}-4 \frac{1}{2}$ & $\begin{array}{l}\text { Total } \\
\text { to } 4 \frac{1}{2}\end{array}$ & $4 \frac{1}{2}-5 \frac{1}{2}$ & $5 \frac{1}{2}-6 \frac{1}{2}$ & $6 \frac{1}{2}-7 \frac{1}{2}$ & $\begin{array}{c}\text { Over } \\
7 \frac{1}{2}\end{array}$ \\
\hline $\begin{array}{c}\text { Rams } \\
\text { A } \\
\text { B } \\
\text { C } \\
\text { D }\end{array}$ & $\begin{array}{r}78 \\
34 \\
44 \\
7\end{array}$ & $\begin{array}{l}1 \cdot 3 \\
2 \cdot 9 \\
0 \\
0\end{array}$ & $\begin{array}{l}19 \cdot 2 \\
20 \cdot 6 \\
18 \cdot 2 \\
42 \cdot 9\end{array}$ & $\begin{array}{l}61 \cdot 6 \\
58 \cdot 9 \\
63 \cdot 6 \\
42 \cdot 9\end{array}$ & $\begin{array}{l}14.1 \\
14.7 \\
13.6 \\
0\end{array}$ & $\begin{array}{l}.96 \cdot 2 \\
97 \cdot 1 \\
.95 \cdot 4 \\
85 \cdot 8\end{array}$ & $\begin{array}{r}3 \cdot 8 \\
2 \cdot 9 \\
4 \cdot 6 \\
14 \cdot 2\end{array}$ & $\begin{array}{l}0 \\
0 \\
0 \\
0\end{array}$ & $\begin{array}{l}0 \\
0 \\
0 \\
0\end{array}$ & $\begin{array}{l}0 \\
0 \\
0 \\
0\end{array}$ \\
\hline $\begin{array}{c}\text { Ewes } \\
\text { A } \\
\text { B } \\
\text { C } \\
\text { D }\end{array}$ & $\begin{array}{r}930 \\
492 \\
43^{\circ} \\
45\end{array}$ & $\begin{array}{l}0 \\
0 \\
0 \\
0\end{array}$ & $\begin{array}{r}9.4 \\
7.3 \\
11.6 \\
8.9\end{array}$ & $\begin{array}{l}63 \cdot 5 \\
63 \cdot 8 \\
63 \cdot 2 \\
71 \cdot i\end{array}$ & $\begin{array}{l}15.6 \\
16.3 \\
14.9 \\
13.3\end{array}$ & $\begin{array}{l}88.5 \\
87.4 \\
89.7 \\
93.3\end{array}$ & $\begin{array}{l}5.4 \\
5.5 \\
5.3 \\
4.5\end{array}$ & $\begin{array}{l}3 \cdot 1 \\
4 \cdot 1 \\
2 \cdot 0 \\
0\end{array}$ & $\begin{array}{l}1 \cdot 7 \\
1.8 \\
1.6 \\
2 \cdot 2\end{array}$ & $\begin{array}{l}1 \cdot 3 \\
1 \cdot 2 \\
1 \cdot 4 \\
1: 4\end{array}$ \\
\hline
\end{tabular}

The data for rams show that they tend to show manifest signs at a rather earlier age than ewes and fewer cases have been observed in old rams.

Table I shows the age distributions obtained for the first series of $5^{26}$ cases (sample B) collected up to June r958 (Parry, r96o), with that for the second series of 482 cases (sample C) collected between July 1958 and December 1960 , and for the total sample of 1008 cases (sample A). Sample D are the progeny of two affected parents. It will be seen that the age group distributions are remarkably close, indicating a constant rate of onset and a high repeatability of the observations. The age distributions for 2 different flock-groups each with over oo cases are very similar.

The close fit of the data for females in sample D with the general age distribution suggests that the genotype of the parents is not important in determining the age of manifestation in any ss offspring, 
and this is confirmed by data for $5^{2}$ affected animals in flocks A and B, 13 of which had both parents affected, 15 had one parent affected and one a heterozygote and 26 had 2 heterozygous parents. The median age of onset for each group was 31 years, with mean ages of $3 \cdot 4,4 \cdot 0$ and 3.5 years respectively.

Many sheepmen maintain that females first pregnant at 8 months old instead of the more usual 20 months develop the disease earlier. We have been unable to confirm this in two flocks in an age-group at present 3 years old. In one flock, of io affected animals 5 lambed as lambs and 5 did not; in the second, of 12 affected 7 lambed as lambs and 5 did not. The youngest cases in both flocks occurred in animals which did not lamb as lambs; 7 of the 22 cases were manifest before $2 \frac{1}{2}$ years of age but only 2 had lambed as lambs.

The age of manifestation does not appear to decrease in successive generations, as the incidence of the disease increases, i.e. " anticipation " does not occur. Thus in flock A, the median age of animals affected in the flock year was $4 \frac{1}{4}$ years when the disease was first noted in 1945 , was $3 \frac{3}{4}$ years in $195^{\circ}$ and $3 \frac{1}{4}$ years in 1951 , since when the median age has remained $3 \frac{1}{4}$ years except in 1956 when it was $2 \frac{3}{4}$ years. Records of other flocks are in general agreement with this conclusion. However, in 6 cases a daughter or son has died of scrapie 12 months or more before their sire or dam was affected and in one instance in flock A, 3 daughters were affected 2 months before the sire was affected. Such examples may be attributed to the normal variation in age of onset and the short inter-generation interval, often of only I year on the male side, rather than to specific "anticipation".

\section{(v) By sex of individuals}

Although the data for rams are less comprehensive than for ewes, there is no clear indication that they are less prone to manifest the disease than the females. Where the male progeny of affected parents have been under observation, they have shown an attack-rate very similar to that of the females. The distribution of the age of manifestation is also very similar (see fig. I).

\section{(vi) By season of the year}

Fig. I shows that more cases occur in the first 6 months of the calendar year, the majority manifesting between October and March, i.e. midwinter in Britain. This coincides with late pregnancy and lactation in the ewe but follows the period of reproductive activity in the ram. It seems likely therefore that some common environmental factor other than reproductive activity may play a major role. This could be nutritional stress, for starving sheep suspected of the disease is employed by some shepherds as a means of hastening the appearance of clinical signs. 


\section{THE 90 PER CENT. MANIFESTATION LEVEL}

Scrapie appears principally in sheep aged $2 \frac{1}{2}-3 \frac{1}{2}$ ycars old (table I, figs. I and 2) and less frequently in older animals. However, cases do develop in older sheep, an important point which will not come to light unless older animals are retained in the flock. For practical purposes it is not feasible to keep large numbers of these older sheep under observation to determine the complete manifestation. However, 89.4 per cent. of our sample of affected animals were manifest by $4 \frac{1}{2}$ years of age. If this figure represents a true estimate of the age distribution of manifestation, then we may accept observation to

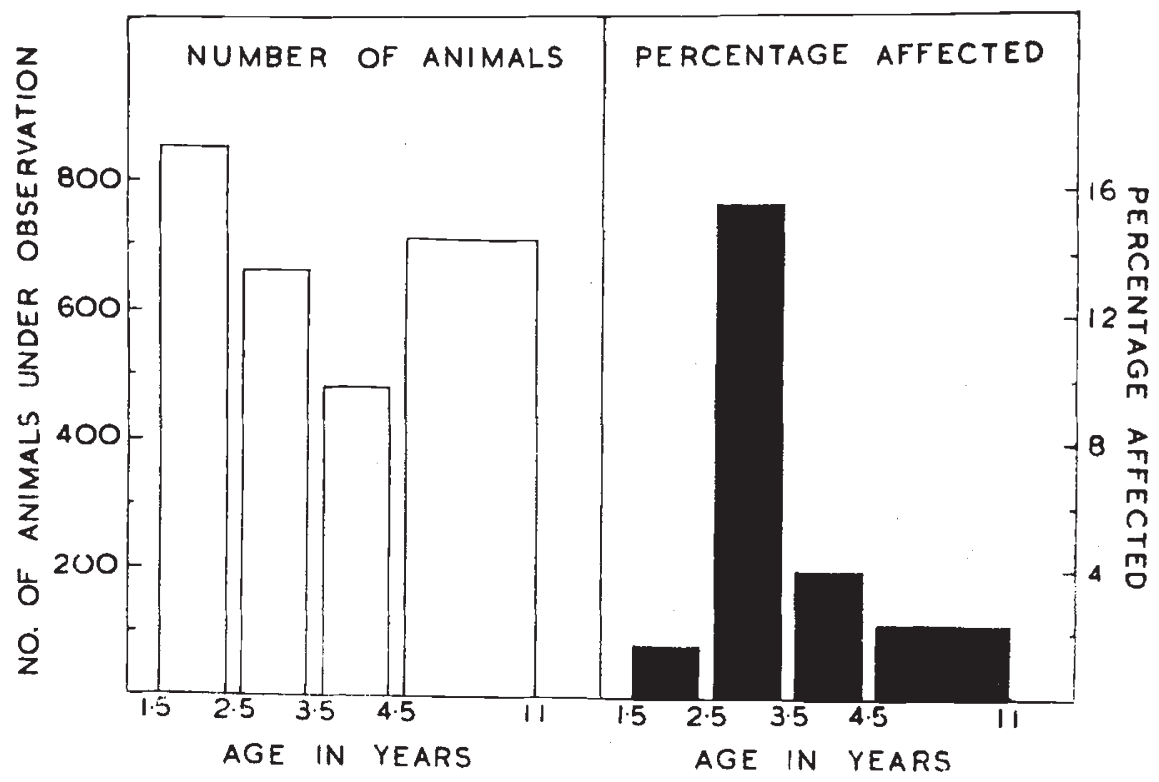

Fig. 3.-The number of ewes of four age-groups kept in flocks A and B during the years 1940-56 with the percentages of each age-group manifesting scrapie.

$4 \frac{1}{2}$ years old as revealing 90 per cent. of all potential cases, while failing to disclose ro per cent, the cases of late manifestation.

The validity of this assumption can be questioned on two grounds. First, if in some flocks or flock-groups the age distribution departed substantially from the normal. From our data this is not so. Secondly, if very few animals older than $4 \frac{1}{2}$ years had been under observation in the flocks providing the samples quoted in table I etc., the true incidence of late manifestation could be seriously underestimated. In the great majority of these flocks, however, I5 to 20 per cent. of the breeding ewes are older than $4^{\frac{1}{2}}$ years. Further, it is only in a small number of flocks in which losses from scrapie are unusually high that there are fewer than 5 per cent. of old ewes. Fig. 3 shows that in flocks $\mathrm{A}$ and $\mathrm{B}$ the number of ewes over $4 \frac{1}{2}$ years old has exceeded 
25 per cent. of the ewes at risk, while having fewer cases than the smaller age-groups of 3- and 4-year-olds.

For males so few are under observation over $4 \frac{1}{2}$ years of age that it is difficult to assess the importance of late manifestation, although they manifest earlier than females (fig. 2). However, our data are concerned so largely with females that any error duc to underestimating late manifestation in males will not seriously distort our age distribution.

We have therefore taken $4 \frac{1}{2}$ years of age as the 90 per cent. manifestation level for all potential cases of scrapic, and have used this age as an arbitrary end-point at whicl to assess all sheep under obscrvation.

An animal alive and well at $4 \frac{1}{2}$ years old and thereafter as long as it may be under observation is termed unaffected. An unaflected animal not under observation until $4 \frac{1}{2}$ ycars of age is called unclassified. An affected animal is one showing unequivocal clinical signs at any age.

\section{EVIDENCE FOR THE GENETIC HYPOTHESIS}

\section{(i) Familial relationships}

In low-incidence flocks affected individuals appeared without any apparent relationship to one another and in different family lines, but with adequate records, these apparently isolated cases were found to have some individual in their pedigree either affected or with a close relative affected. Afiected individuals tended to be the progeny of a very small group of ewes and rams, and the ewes had a sire or grandise in common. A ewe producing an affected offspring by one ram, often produced unaffected progeny by other rams at previous and subscquent matings, although the flock incidence remained similar. The unaffected progeny of such a ewe not infrequently had offspring which manifested the disease. In high-incidence flocks many affected individuals had affected parents or progeny affected.

In one flock (flock A), the records have permitted a more critical study of the family rclationships of $9^{8}$ affected animals. The discase manifesting itself in this flock is quite typical of scrapie as encountered in this flock-group. Losses from causes other than scrapie arc low, while the productivity of the flock is high and the flock has an excellent record at agricultural shows. 'Thus flock A would appear to be fully representative of this flock-group.

In flock $A$, of 826 breeding females introduced into the flock between 1937 and 1957,98 had manifested the disease by 1959 . Fifty rams have been used; 49 have becn purchased from 20 other flocks, of which 14 are known to have had the discase scriously at the time the rams were born and reared, four are known to have had very little or no scrapic and the status of two is unknown; 45 of the 50 rams left progeny in the flock.

Fiftecn of the 45 rams were used for threc scasons or longer, and left many offspring retained in the flock. Of the fifteen, four manifested scrapie, and threc others produced affected progeny when mated with affected ewes, i.e. ewes cither affected during that gestation, or subsequently manifesting the diseasc. Three 


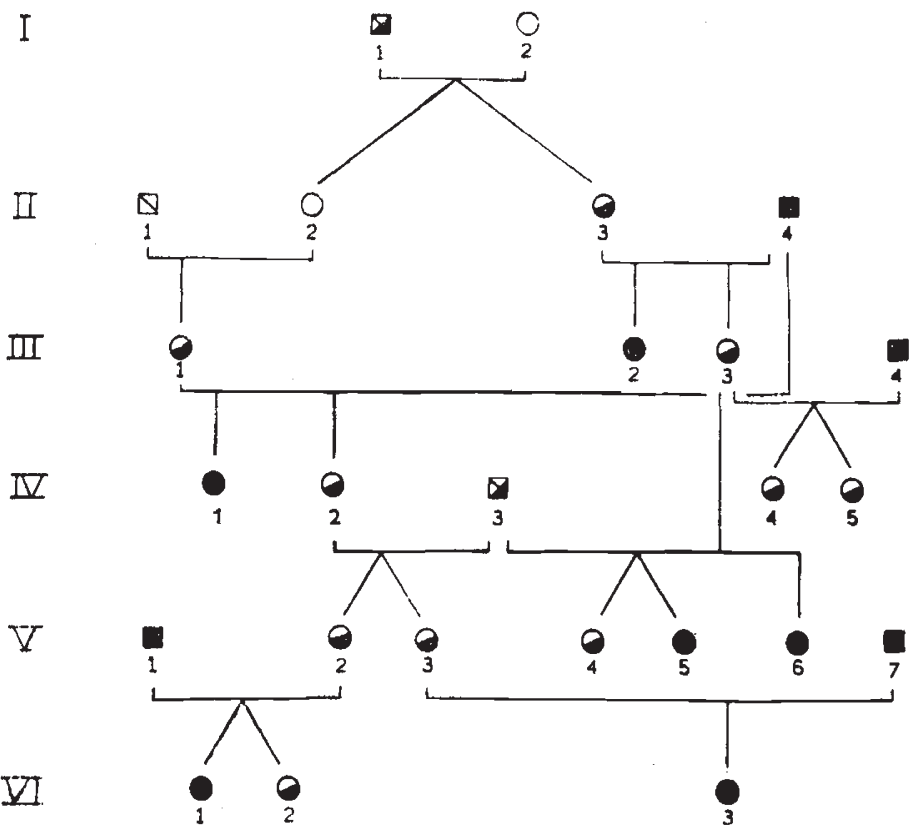

Fig. 4.

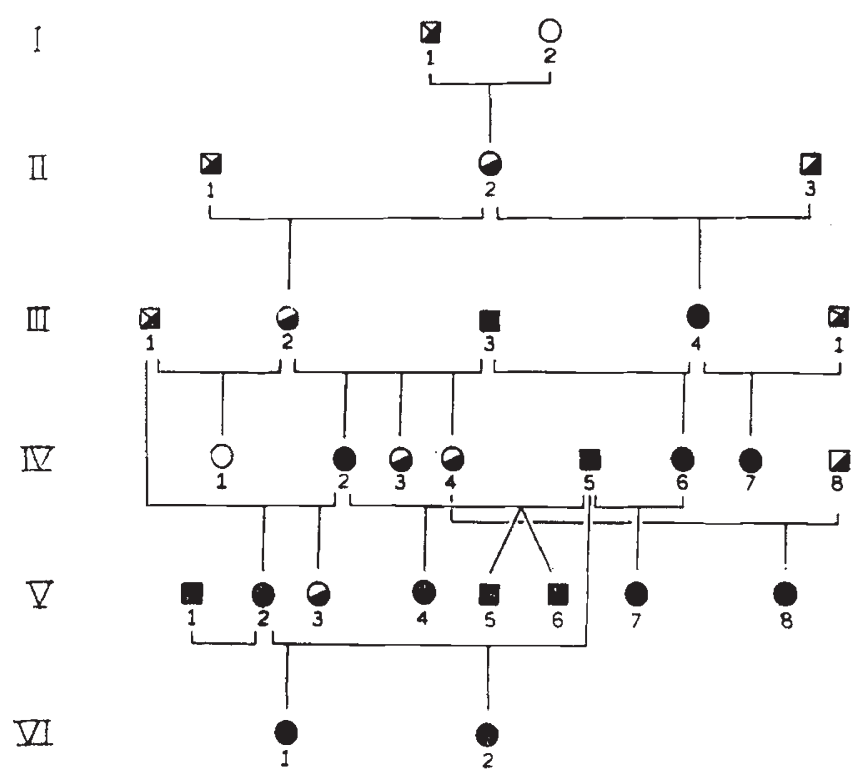

Fic. 5.

FIGs. 4 and 5.-Two pedigrees illustrating familial relationships and the increased incidence following the use of $S s$ and ss rams.

- affected, i.e. ss.

(D) Unaffected, but with more than one affected progeny or a parent affected, i.e. Ss with o per cent. ss.

$\nabla \otimes$ Unclassified, i.e. unaffected but not under observation until $4 \frac{1}{2}$ years old.

$\square$ Unaffected with no parent or progeny affected, i.e. SS or Ss. 
more sired affected progeny and against five there is no cvidence of close relatives being affected.

The remaining 30 of the 45 rams were retaincd for less than three seasons, in the majority for one season only and were then culled as being unsatisfactory sires, leaving few offspring in the flock. Their proneness to scrapic is thereforc undetermined. Of these, four produced affected offspring and against 26 there is no information about close relatives.

Of the 98 females manifesting scrapic, the sires of 89 are known; 23 were the progeny of affected rams, $5 \mathrm{I}$ werc sired by rams which produced affected progeny out of ewes which became affected, 13 werc sircd by rams siring more than one affected progeny and two cases were by rams siring a single case. Of the females the dams of 34 per cent. of the cases were themselves affected, while of the 35 daughters of affected ewes retained in the flock "to 90 per cent. risk", 32 were affected. Seven affected ewes produced two or more affected progeny.

In matings in which the sirc later manifested the disease but the ewes did not, 19 female progeny living to $4 \frac{1}{2}$ ycars have shown no sign of the discase, while of matings in which the sire never manifested the diseasc but the ewe did, four femalc progeny have been normal to the same age or older.

In five pedigrees the disease occurs in threc consecutive generations; in seven the disease has missed onc gencration between two affected individuals. There is a very high attack-ratc among the progeny of two affected parents, but the progeny of a mating with one parent affected may be unaffected. The pedigrees shown in figs. 4 and 5 illustrate these points.

These data suggest that the manifestation of scrapie may be genetically determined and that, if this hypothesis be correct, then the factor or factors are not sex-linked and do not behave as a simple dominant. The evidence could be consistent with a disease controlled by a simplc autosomal mendelian recessive character.

\section{(ii) Breeding results}

The records from two flocks, $A$ and $B$, have been analysed for the period 1940-59. In flock $\mathrm{A}, 9^{1} 7$ breeding females and 53 stud rams have been used, and in flock B 1108 brecding females and 73 stud rams. The stud rams have been coded on their own performance (i.e. their manifestation of scrapie or not) and that of their progeny; the records of their parents are rarely complete enough to provide any further assessment of their presumptive genotypes. With the breeding females the performance of their parents and often their grandparents, are known, information which may be supplemented in some cases by the performance of other progeny of the parents and grandparents. Thus for the dams their coding has been based on the parental performances plus their own performance, but the performance of their progeny has been excluded. The details are given in table 2. The categories of the matings have been devised to follow the range of matings possible between the three presumptive genotypes, $S S, S s$ and ss. In categories I, 2, 3, 5, 8 and 9, the genotypes of the parents may be inferred with precision, but in the 


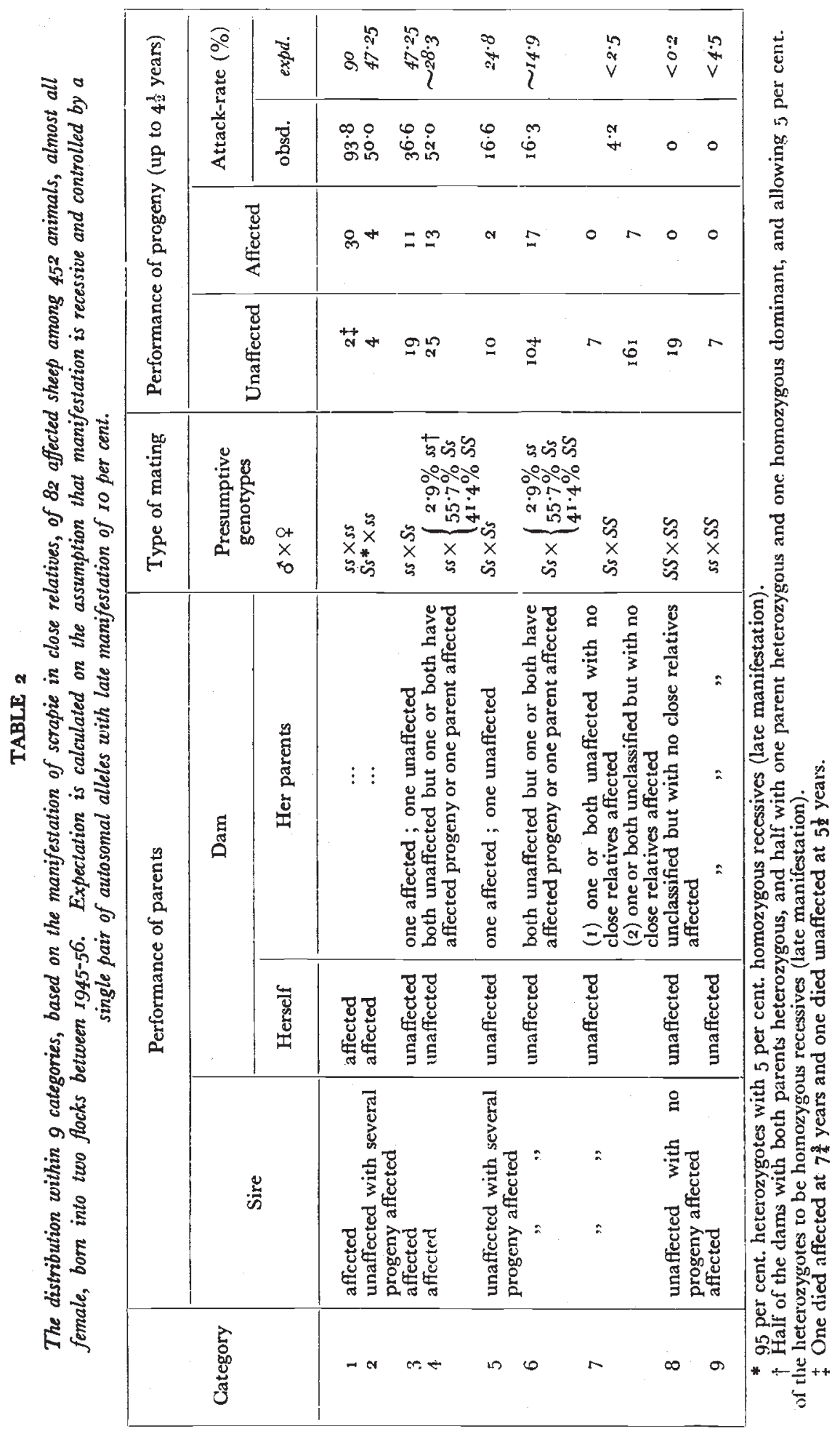


categories 4,6 and 7 the genotypes of the dams are not known precisely. The following points may be stressed:

(I) the attack-rate shows a gradation from 93.8 per cent. in category $\mathrm{I}$ to o per cent. in categories 8 and 9 .

(2) the closeness of fit between the observed attack-rate for each category and that expected on the genetic hypothesis is good.

(3) In category 3 the low attack-rate may prove to be due to genetically determined late manifestation, as 20 of 30 animals are the progeny of one sire, and 15 remain under observation.

(4) In categories 4 and 7 there is likely to be an underestimation of $S s$ individuals, since they will go unrecognised unless several progeny of their matings with $S s$ or ss sires are kept under observation. The high manifestation in category 4 could be accounted for by preferential selection of heterozygotes over homozygous dominants, which, as we shall see later, is likely to occur.

(5) In category 5 the percentage affected is too low, but the number of animals is small. In the larger series of $S s \times S s$ matings in table 3 (iii) the expected percentage is observed.

The goodness of fit between the observed figures for these two flocks and the genetic model is satisfactory. The data were therefore examined for certain evidence crucial for the mendelian recessive hypothesis.

\section{(iii) The recessive gene hypothesis}

(a) The mating ss $\times$ ss (table 3 (i)). Although only 55 progeny from this type of mating have been under observation to the 90 per cent. manifesfation level, there are over roo animals under observation. The data on 93 animals assessed to July 1959 have been published (Parry, 1960); table 3 (i) presents these data corrected to December r 960 , and includes six males over $2 \frac{1}{2}$ years, of which four are affected. The expected manifestation factor or expectation expressed as a decimal, has been derived from the curve given in fig. 2 .

The cumulative totals refer to all animals which can be classified at the stated age. The number at risk represents the sum of the animals of each age-group born from 1952 onwards, which have been retained under observation. The wastage from cases other than scrapie has been small; of the 97 animals included at age 2 years, five have been lost from miscellaneous accidental causes-three at 2 years, one at 3 years and one at 6 years, while two have died of a post-partum pining syndrome, which appears to be related to scrapie. Thus the wastage from competing risks is not large enough to distort significantly the closeness of fit.

These animals are from four flocks, three of which represent medium to high incidence environments, and $\mathrm{I}$ is a low incidence environment; there are four animals from the latter. Thus it seems 
unlikely that these results are influenced greatly by environmental influences, preferential mortality or sex. close.

The fit between the observed and expected figures is extremely

(b) The mating ss $\times S S$ (table 3 (ii)). A flock, which had recorded all cases of death and disposal on account of ill-health for over 30 years, had had no recognised case of scrapie. The presumptive gene

TABLE 3

Manifestation among the progeny of 3 types of mating showing the cumulative totals in (i) and (ii) and the simple totals in (iii) of affected animals, observed and expected on the recessive hypothesis

\begin{tabular}{|c|c|c|c|c|c|c|c|c|}
\hline \multirow{2}{*}{ Type of mating } & \multicolumn{8}{|c|}{ Progeny-age in years } \\
\hline & 1 & 2 & 3 & 4 & 5 & 6 & 7 & 8 \\
\hline $\begin{array}{l}\text { (i) ss } \times \text { ss } \\
\text { No. at risk* } \sigma^{*} \sigma^{*}+\text { 우 } \\
\text { Expectation } \dagger \\
\text { No. affected- } \\
\text { observed . } \\
\text { expected . }\end{array}$ & $\begin{array}{r}103 \\
100 \\
0 \\
0\end{array}$ & $\begin{array}{r}97 \\
103 \\
1 \\
3 \cdot 4\end{array}$ & $\begin{array}{c}58 \\
157 \\
28 \\
33^{\circ} \circ\end{array}$ & $\begin{array}{r}56 \\
186 \\
47 \\
48 \cdot 0\end{array}$ & $\begin{array}{c}53 \\
193 \\
\\
50 \\
49 \cdot 2\end{array}$ & $\begin{array}{c}52 \\
\cdot 97 \\
\\
50 \\
50 \cdot 6\end{array}$ & $\begin{array}{c}5 \mathrm{l} \\
\cdot 9^{8} \\
\\
50 \\
50 \cdot I\end{array}$ & $\begin{array}{c}51 \\
\cdot 99 \\
51 \\
50 \cdot 6\end{array}$ \\
\hline 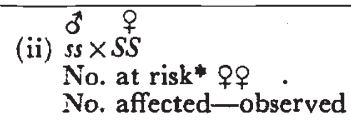 & $\begin{array}{l}\cdots \\
\cdots\end{array}$ & $\begin{array}{r}3^{6} \\
0\end{array}$ & $\begin{array}{r}31 \\
0\end{array}$ & $\begin{array}{r}16 \\
0\end{array}$ & $\begin{array}{l}5 \\
0\end{array}$ & $\ldots$ & $\begin{array}{l}\ldots \\
\cdots\end{array}$ & $\begin{array}{c}\cdots \\
\cdots \\
\cdots\end{array}$ \\
\hline $\begin{array}{l}\text { (iii) } S s \times S s \\
\text { Age group : oㅇ } \\
\text { No. under observation } \\
\text { No. affected- } \\
\text { observed } . \\
\text { expected } \ddagger \text {. }\end{array}$ & $\begin{array}{l}\cdots \\
\cdots \\
\cdots\end{array}$ & $\begin{array}{r}2 \pm \frac{1}{2} \\
122 \\
3 \\
3 \cdot 2\end{array}$ & $\begin{array}{c}3 \pm \frac{1}{2} \\
108 \\
30 \\
23\end{array}$ & $\begin{array}{c}4 \pm \frac{1}{2} \\
59 \\
11 \\
5 \cdot 5\end{array}$ & $\begin{array}{r}5 \pm \frac{1}{2} \\
28 \\
4 \\
x \cdot 7\end{array}$ & $\begin{array}{c}6 \pm \frac{1}{2} \\
16 \\
1 \\
o\end{array}$ & $\begin{array}{c}7 \pm \frac{1}{2} \\
5 \\
0 \\
0\end{array}$ & $\begin{array}{c}8 \pm \frac{1}{2} \\
2 \\
0 \\
0\end{array}$ \\
\hline
\end{tabular}

* Sum of unaffected and unclassified animals under observation up to the stated age plus all those affected.

$\dagger$ Calculated from the cumulative percentages of observed manifestation (table I and fig. I) and adjusted for the sex ratio.

+ Allowing 10 per cent to be unaffected presumptive ss animals.

frequency for scrapie in this flock is low, and one may assume that most of the females are SS. A ram was introduced into this flock in ig55 from a medium-incidence flock, and used extensively for three mating seasons. Six months after the third season the ram manifested classical scrapie. Thirty-six progeny of this ram have been retained in the flock and are under observation. No case of scrapie has appeared yet in any females in this flock, although five are now 5 years old.

(c) The mating $S s \times S s$ (table 3 (iii)). On the recessive hypothesis animals with progeny affected or with one parent affected must carry the gene; and if they remain unaffected until $4 \frac{1}{2}$ years of age they must be heterozygotes, but with Io per cent. homozygous recessives of late manifestation. 
On this assumption the records of flocks $A$ and $B$ for all females retained in the years $1944-58$ have becn scrutiniscd for presumptive Ss $\times$ Ss matings. Table 3 (iii) shows that although the observed manifesation is of the right order, it exceeds that expected by about 50 per cent. This is probably due to the preferential selection of homozygous recessives, which are often superior individuals (see Section 9). In several instances where twin ewe lainbs were born and reared, only one has been retained and this one has manifested scrapie. The sample under observation will thus tend to be weighted in favour of homozygous recessive individuals. This tendency will also be accentuated by the usual policy of culling all sibs and half-sibs of an affected animal, which in this type of mating are much less likely to be homozygous recessives than their affected relatives.

An estimate of the amount of this bias in the data is not possible, but the bias is in the right direction and probably of the right order. The full answer must await the results of experimental matings which are in hand.

(d) Fluctuation in incidence. One of the more baffling aspects of the natural history of scrapie has been the oft-observed sudden waxing and waning of the attack-rate over a relatively short period of years. The extreme polygamy with three males per 100 females might be expected to give such high fluctuation if a recessive factor were involved.

Prelininary studies of the effect of the use of sires of different scrapie genotypes on the expected gene frequency of the breeding females in a flock indicatc that the genetic hypothesis will explain these epidemiological fluctuations in terms of population genetics without postulating any infection (Draper and Parry, unpublished).

\section{EVIDENCE AGAINST THE NATURAL INFECTION AND ENVIRONMENTAL HYPOTHESES}

(i) Contact between affected and unaffected flock-groups

On three farms with high-incidence flocks, other sheep of flockgroups believed to be free of scrapie, have been kept alongside and often intermingled with the affected flocks for at least five years. One contact flock was i 10 recorded pedigree sheep retaining some of its females for brecding, and two were non-recorded commercial flocks of 150 and 500 ewes not breeding their flock replacements. No case of scrapie has been observed in two flocks, but one case has appeared in the 150 -ewe flock in a cross between breeds now known to sufler from scrapie.

On one farm with a high-incidence flock disposed of on account of scrapie, several hundred breeding sheep from a scrapie-free flockgroup were introduced on to the same fields, somc before all the affected flock were removed. No case of scrapic has occurred in the newly introduced sheep in five years. 
A flock of 400 ewes acquired by purchase from three source-flocks and using several rams developing scrapie during or shortly after the communal mating, had cases of scrapie confined to the females and their progeny from one source-flock, which, it was learnt subsequently, had been dispersed on account of the high incidence of scrapie.

Evidence in the literature purporting to support mediate contagion is now inadmissible owing to the inadequate knowledge of the genotypes of the sheep. More adequately controlled evidence is required; studies on the introduction of animals of low gene frequency into high gene frequency flocks have been in hand for two years without any signs of contagion.

\section{(ii) Contact by coitus}

In two flocks of low presumptive gene frequency on three occasions rams developing scrapie within I-3 months of the mating season have been used. No case has occurred in the flock ewes mated by them up to three years thereafter.

In an experiment using 70 animals of known genotype, non-ss rams and ss rams affected at the time of mating have been mated with non-ss and ss ewes, many of which were affected at the time of mating. After $3 \frac{1}{2}$ years no case of scrapie has yet developed in any animal not of presumptive ss genotype.

We have found no evidence from our general field observations that scrapie is spread by coitus except through the genemechanism.

\section{(iii) Contact during gestation and suckling}

Records are availabie for 23 animals whose dams manifested scrapie during their late gestation and/or early suckling (table 4); the

TABLE 4

Manifestation among 23 daughters born of " ss" ewes affected at the time of their gestation and suckling

\begin{tabular}{|c|c|c|c|c|c|}
\hline \multicolumn{3}{|c|}{ Type of Mating } & \multicolumn{3}{|c|}{ Progeny } \\
\hline \multirow{2}{*}{ Sire } & \multirow{2}{*}{\multicolumn{2}{|c|}{ Dam }} & \multirow{2}{*}{ Unaffected } & \multicolumn{2}{|c|}{ Affected } \\
\hline & & & & observed & expected \\
\hline ss & $x$ & ss & 2 & 10 & $10 \cdot 8$ \\
\hline Ss & $x$ & ss & 6 & 5 & 4.95 \\
\hline
\end{tabular}

observed and expected figures agree. They lend no support to the idea that the manifestation of scrapie during a ewe's gestation and lactation renders her offspring of that pregnancy more liable to 
develop scrapie. Two lambs of affected ewes reared on unaffected foster-mothers have been unaffected.

Data on the results of ova transfer of $s s \times s s$ zygotes into $S S$ recipient ewes and vice versa should provide further evidence on this point.

\section{(iv) Birth order}

As certain neurological disorders in man appear to be more frequent among later-born children, the birth order of II I affected females in flock A has been examined.

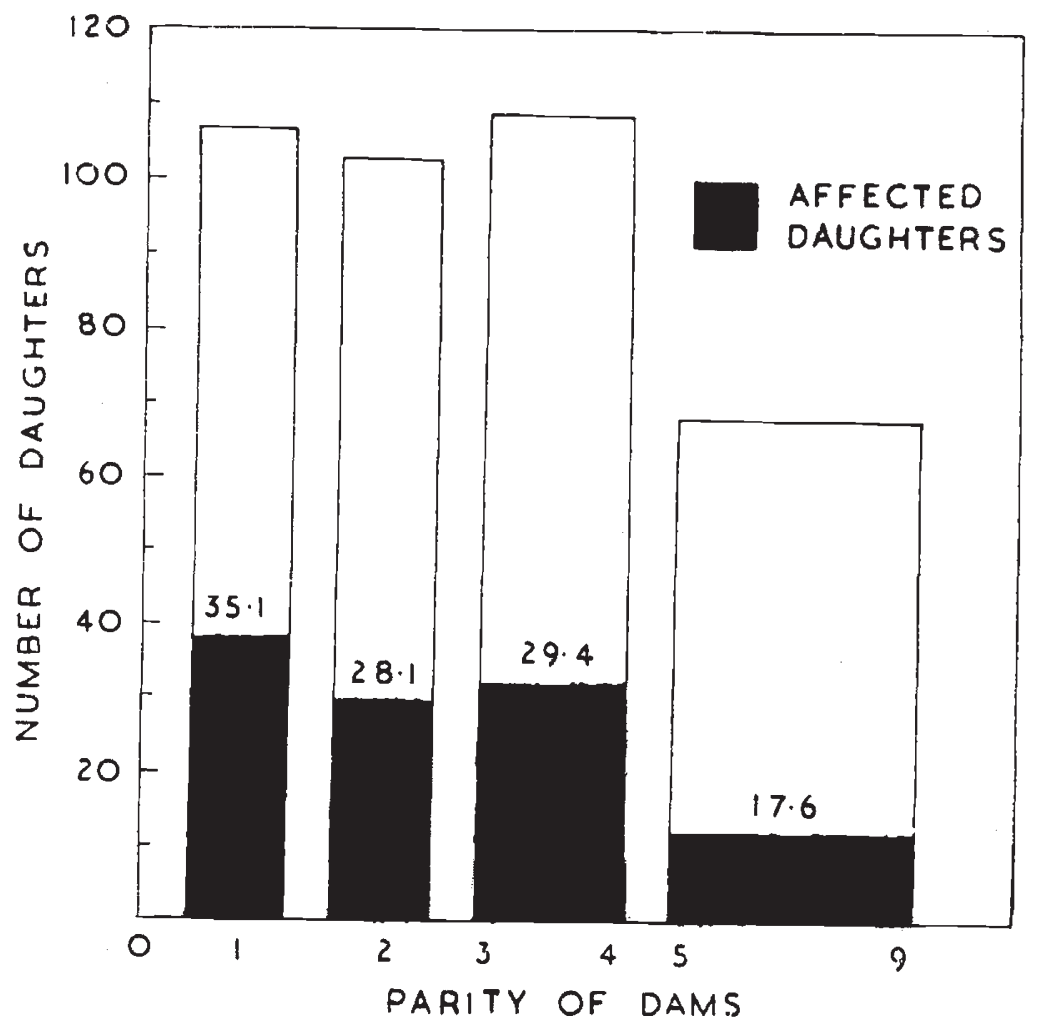

FIG. 6.- The total numbers of daughters born to ewes of different parity and retained in flocks A and B (during the years $1940-56$ ), with those manifesting scrapie (figures within the blocks indicate percentages of total at risk).

For the present purpose the birth order has been taken to be synonymous with the parity of the dam at the time the affected animal was born. This is not strictly correct, since the birth order should take account of all the lambs born in gestations previous to the one in which the individual is born. However, for our present purpose this approximation will suffice.

Fig. 6 shows that affected animals may be born at any period of a ewe's reproductive life. A higher proportion of the offspring of the younger ewes than of the older ewes are affected. If an infection were involved, one would expect these proportions to be similar, or 
even to be higher among the progeny of the older ewes. This higher susceptibility with lower parity is due to the selective mortality of ss ewes in the age-groups up to $4 \frac{1}{2}$ years, so that the frequency of the scrapie gene among older ewes will be lower than among the younger ewes.

These results are consistent with other data which also indicate that birth order does not influence directly the manifestation of scrapie.

\section{(v) Gestational twins}

It is generally considered that uniovular twins are rare in sheep; they are certainly very rarely detected at birth. In flock B for the

TABLE 5

Manifestation among 83 sets of fraternal twins from five mediumto high-incidence flocks

\begin{tabular}{|c|c|c|c|c|c|c|}
\hline \multirow{2}{*}{$\begin{array}{l}\text { Category } \\
\text { (table 2) }\end{array}$} & \multirow{2}{*}{ Mating } & \multicolumn{3}{|c|}{ No. of sets of twins } & \multicolumn{2}{|c|}{ Total affected } \\
\hline & & $\begin{array}{c}\text { Both } \\
\text { affected }\end{array}$ & $\begin{array}{l}1 \text { affected } \\
1 \text { unaffected }\end{array}$ & $\begin{array}{c}\text { Both } \\
\text { unaffected }\end{array}$ & obsd. & $\operatorname{expd}$. \\
\hline \multicolumn{7}{|l|}{$\begin{array}{c}\text { Mixed } \\
\text { progeny }\end{array}$} \\
\hline $\begin{array}{l}1 \\
2\end{array}$ & $\begin{array}{l}s s \times s s \\
\text { Ss } \times s s\end{array}$ & $7^{*}$ & $2 \dagger$ & o & 16 & $16 \cdot 1$ \\
\hline 3 & 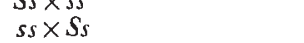 & 5 & 2 & 0 & 12 & $6 \cdot 3$ \\
\hline 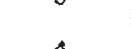 & 2.9 per cent. ss & & 3 & 7 & 5 & $9 \cdot 9$ \\
\hline 4 & $s s \times\left\{\begin{array}{l}55: 7 \text { per cent. } S s \\
4 \cdot 1 \cdot 4 \text { per cent. } S S\end{array}\right.$ & 0 & 2 & 2 & 2 & $2 \cdot 2$ \\
\hline 5 & $\int_{s} \times S_{s} 2.9$ per cent. $s s$ & 3 & 2 & 4 & 8 & $4^{\circ} 0$ \\
\hline 6 & $S s \times \begin{cases}55.7 & \text { per cent. } S s \\
41^{\circ} \cdot 4 & \text { per cent. } S S\end{cases}$ & I & $5 \neq$ & 16 & 7 & $6 \cdot 3$ \\
\hline Total & 62 & 17 & 16 & 29 & $\cdots$ & $\cdots$ \\
\hline \multirow{3}{*}{$\begin{array}{c}\text { Uniform } \\
\text { progeny } \\
7 \\
8 \\
9\end{array}$} & & & & & & \\
\hline & $S s \times S S$ & 0 & 0 & 13 & 0 & $o$ \\
\hline & $s s \times S S$ & $\begin{array}{l}0 \\
0\end{array}$ & 0 & 7 & $\begin{array}{l}0 \\
0\end{array}$ & $\begin{array}{l}o \\
o\end{array}$ \\
\hline Total & 21 & 0 & 0 & 21 & $\ldots$ & $\ldots$ \\
\hline
\end{tabular}

* I pair of rams and I pair - I ram and I ewe.
$\dagger 2$ unaffected animals now 42 years old.

† pair-affected ram and unaffected ewe.

period $1944^{-6 r}$, of $\mathrm{r} 349$ sets of twins recorded, 670 were of like sex (314 males and 356 females) and 679 were of unlike sex, a ratio of 0.99 to $\mathbf{I}$. We are assuming therefore, for the present purpose, that gestational twins are binovular.

One hundred and six sets of twins have been under observation 
until $4 \frac{1}{2}$ years old in six flocks of low to high incidence. One hundred and one sets were both female, four a male and a fernalc and onc set were both males. In 17 sets both were affected, in 26 one was affected and one unaffected and in 63 both were unaffected. These data suggest that intra-uterine influences were not important and they were therefore examined in the light of the genetic hypothesis. Table 5 gives the results for 83 sets of twins with the necessary parental records. The number of sets in each category is small, but the results show a clear trend which is consistent with the genetic hypothesis.

\section{(vi) Progenies of different sires in an affected flock}

If scrapie is due to a recessive gene, then the attack-rate among the daughters of sires of different genotype should be very different,

TABLE 6

Manifestation among the daughters born to three rams in 1.955-56 and retained in the same flock (flock $A$ )

\begin{tabular}{|c|c|c|c|c|c|c|c|c|c|}
\hline \multicolumn{2}{|c|}{ Sire } & \multicolumn{2}{|c|}{ Dam } & \multicolumn{4}{|c|}{ Daughters } & \multirow{2}{*}{\multicolumn{2}{|c|}{$\begin{array}{c}\text { Flock } \\
\text { attack-rate }\end{array}$}} \\
\hline \multirow{2}{*}{ Category } & \multirow{2}{*}{$\begin{array}{c}\text { Pre- } \\
\text { sumptive } \\
\text { genotype }\end{array}$} & \multirow{2}{*}{$\begin{array}{l}\text { Category } \\
\text { (table 2) }\end{array}$} & \multirow{2}{*}{$\begin{array}{c}\text { Pre- } \\
\text { sumptive } \\
\text { genotype }\end{array}$} & \multirow{2}{*}{$\begin{array}{l}\text { Un- } \\
\text { affected }\end{array}$} & \multirow{2}{*}{ Affected } & \multicolumn{2}{|c|}{$\begin{array}{l}\text { Attack-rate } \\
\text { per cent. }\end{array}$} & & \\
\hline & & & & & & obsd. & expd. & Year & $\begin{array}{c}\text { Per } \\
\text { cent }\end{array}$ \\
\hline Affected & ss & $\begin{array}{c}1 \\
3 \text { and } 5 \\
7 \text { and } 8\end{array}$ & $\begin{array}{l}s s \\
S s \\
S S\end{array}$ & $\begin{array}{r}0 \\
23 \\
3\end{array}$ & $\begin{array}{r}11 \\
17 \\
0\end{array}$ & $\begin{array}{c}100 \\
42 \cdot 5 \\
0\end{array}$ & $\begin{array}{l}90 \\
47 \cdot 25 \\
0\end{array}$ & $\begin{array}{l}1955 \\
1956 \\
1957\end{array}$ & $\begin{array}{r}7 \cdot 2 \\
12 \cdot 1 \\
16 \cdot 7\end{array}$ \\
\hline $\begin{array}{l}\text { Unaffected and } \\
\text { unclassified }\end{array}$ & Ss & $\begin{array}{c}1 \\
3 \text { and } 5 \\
7 \text { and } 8\end{array}$ & $\begin{array}{l}s s \\
S s \\
S S\end{array}$ & $\begin{array}{r}2 \\
8 \\
\ldots\end{array}$ & $\begin{array}{r}2 \\
4 \\
\cdots\end{array}$ & $\begin{array}{l}50 \\
33 \cdot 3\end{array}$ & $\begin{array}{c}47 \cdot 25 \\
24 \cdot 8 \\
\ldots\end{array}$ & $\begin{array}{l}1958 \\
1959 \\
1960\end{array}$ & $\begin{array}{r}12.6 \\
18.6 \\
9.1\end{array}$ \\
\hline
\end{tabular}

and independent of the high incidence environment, provided that the proportion of dams of each genotype mated to each sire is sinilar. In only one flock has it been possible to assemble data relevant to this point. These are given in table 6 , from which it will be seen that the total attack-rate among 54 progeny of an affected ram is higher than among the I I progeny of an unaffected ram, and five of an unclassified ram. When these attack-rates are subdivided according to the presumptive genotypes of the dams, a clearer picture emerges, and the observed and expected values agree well.

These results do not suggest that even in a very high incidence flock is the manifestation influenced in any way by the environment. Special matings with $s s$ and $S S$ animals maintained in a similar high incidence environment have been made, but it is as yet too early to assess the results. 


\section{EVIDENCE FOR ARTIFICIAL INFECTION}

\section{(i) Previous studies}

Early attempts to demonstrate an infective agent, using in the main blood and secretions as the inocula, proved unsuccessful, but Cuillé and Chelle in 1936 reported the successful transmission of a scrapielike disease to sheep by using suspensions of affected sheep brain. Many investigators have since confirmed that the tissues of scrapie animals contain a transmissible agent (see Palmer, 1959; Pattison, Gordon and Millsom, 1959; Stamp, Brotherston, Zlotnik, Mackay and Smith, 1959; Pattison and Millsom, 1960; Mackay, Smith and Stamp, 1960).

The agent has the following properties:

(i) It has not been demonstrated in the tissues of clinically normal sheep.

(ii) It is present in a wide variety of tissues of affected animals, e.g. brain, pituitary, adrenal, spleen, pancreas, liver and lymph nodes, and in cerebro-spinal fluid.

(iii) It is self-replicating and appears to accumulate slowly over several months in the tissues of recipient animals following inoculation and its presence can be demonstrated before the onset of clinical signs. It is only known to be pathogenic for sheep and goats and one strain of mice.

(iv) All attempts to grow the agent in bacterial and tissue culture have failed; it will pass through gradocol membranes of 410 $\mathrm{m} \mu$ A.P.D., but not of $27 \mathrm{~m} \mu$ A.P.D.

(v) It is extremely stable. Homogenates of affected brain ( $\mathrm{I}$ in Io $\mathrm{w} / \mathrm{v}$ in normal saline) are still active after 42 days at room temperature and heating to $99.5^{\circ} \mathrm{C}$. for 30 minutes, but are inactivated by autoclaving at 220 p.s.i. for 30 minutes; they are not inactivated by 0.35 per cent. formalin, nor by treatment with acetylethyleneimine under condicions 50 per cent. more rigorous than those required to inactivate II animal viruses and tobacco mozaic virus.

(vi) Attempts to demonstrate the systemic immunological reactions commonly present in mammalian virus infections have failed (Chandler, 1959), and whole body irradiation of newborn lambs has not enhanced the susceptibility of the recipient animals to the agent (Mole and Parry, unpublished).

(vii) No spread of the experimental disease in goats to 28 uninoculated goats has been observed after 24 to 36 months (Pattison and Millson, 1960), while Stamp et al. (r959) have failed to set up the disease by feeding scrapie brain to 10 new-born lambs, which were kept under observation for 12 months. 


\section{(ii) The hereditary disease}

To show that the disease arising under controlled breeding conditions was also transmissible by inoculation and was, in fact, the same as the scrapie disease used in these previous inoculation studies, the following experiment was carried out. Portions of the medulla, pons and cerebral hemispheres of a pure-bred ewe, $4 \frac{1}{2}$ years old, showing the typical signs of scrapie, and from a flock with a moderate to high incidence of the disease, showing the genetic pattern, were ground up separately in two portions, one with normal saline and one with broth, in the approximate proportions of one part brain to ten parts medium. The homogenates were centrifuged at 3500 r.p.m. for Io minutes and within two hours the supernatant was inoculated into the left parieto-occipital region of lambs.

The lambs, born in 1957 , were 4 to 24 days old and suckling their dams, which were of two breeds; the sires of the lambs were of two breeds. The sires and dams were normal and thought at the time to be clear of scrapie, but in the light of recent knowledge, their presumptive genotypes are now less certain. In two of the three breeds of the parents, scrapie is probably extremely rare, but in the third it does occur. Of ten lambs, five were inoculated and five were left uninoculated as controls, each paired as far as possible for weight, sex, age and parentage, and reared together on their dams in the open.

The five inoculated lambs developed clinical signs of a scrapielike illness, in the females at 12, 14 and 22 months and in the males at 13 and 14 months after inoculation. One control animal was killed at 17 months for comparison with its fraternal twin which had been inoculated; the remainder were alive and well at 30 months.

The morbid anatomical and histological lesions in the inoculated sheep were similar to those seen in natural scrapie, and reported for the artificially induced disease.

Thus the tissues of a sheep suffering from a typical form of hereditary scrapie will, when inoculated into young lambs, cause a scrapie-like syndrome to develop in the recipient animals at an age when the natural disease is not known to occur. An affected ss animal thus contains a transmissible agent which is artificially infectious.

\section{GENETIC PROBLEMS OF SCRAPIE \\ (i) Selection pressure fovouring lethal genes}

When a lethal recessive gene is present in a population, its frequency normally remains very low unless the gene confers some selective advantage. This advantage is usually expressed in the heterozygote, as the lethal action of the gene in the homozygote is commonly manifested relatively early in life. The sickling trait in man is an example; 75 per cent. of the homozygotes die of sickle-celled anæmia 
before reproductive age, but the heterozygotes are resistant to malaria and have a marked advantage in malarial regions. Thus in parts of Africa 40 per cent. of the breeding population are carriers, the gene frequency is as high as 0.25 and the homozygote frequency 0.065 (Allison, I954-55).

With scrapie we have no means of easily detecting the heterozygotes but the attack-rate is not uncommonly as high as I0-I 5 per cent. of a birth-group. In one flock in which almost all the females born have been kept under observation to $5^{\frac{1}{2}}$ years old, the attackrates in 6 successive birth-groups have been $70,5^{\circ}, 5^{8}, 3^{2}, 69$ and 74 per cent. To give such a proportion of recessive homozygotes, a gene frequency as high as 0.8 and more is required. Thus the frequency of the scrapic gene must be 0.3 to 0.4 in many flocks and reach 0.8 occasionally.

Gene frequencies of this order are not usually encountered with lethal genes and require special circumstances for their occurrence. These are present in scrapie and are quantitatively sufficient to cnsure. gene frequencies of these magnitudes (Draper and Parry, unpublished); they are:

(a) The extreme polygamy, one male to $30-40$ fenales, inherent in current sheep breeding practice, makes the rams' genotype of supreme importance. Should a lethal gene become associated with the preferred ram phenotypes, then such a gene would become widely disseminated through a flock-group within 5 to ro years.

(b) This dissemination is much more rapid if males homozygous for the lethal gene are used, when flock gene frequencies of 0.8 would be possible. For such a situation the recessive homozygotes must live through at least part of their reproductive life. As rams usually begin breeding at 8 months of age, scrapie rams have at least two and often three or four breeding seasons before they manifest, and the ss genotype, both male and female, which are highly fertile and prolific, retain their full reproductive powers until clinical illness is far advanced. There is thus every opportunity for the dissemination of a gene of the scrapie type, if its effect is favourable in adolescence and early adult life.

(c) If such a lethal gene does not manifest until relatively late in life, disadvantage will not operate until after reproduction is assured and the gene will not be discriminated against unless special breeding programmes are undertaken. With scrapie the manifestation provides a pattern so complex that the genetic basis of the disease has not hitherto been accepted, and the efforts of individual flockmasters to limit the spread of the disease by selection has not produced any marked disadvantage against the dissemination of the gene.

G 
(d) Under these circumstances any advantage, however small, possessed by the heterozygote and recessive homozygote which leads to their sclection for breeding and especially as stud rams, will be sufficient to ensure the widespread dissemination of the gene.

\section{(ii) Selective advantages of the Scrapie gene}

The scrapie gene is, in fact, linked with certain phenotype characteristics which are highly preferred by the leading flocks of several breeds.

The stud rams of the leading flocks of several affected breeds tend to be selected from a small group of animals which have been prizewinners at the leading agricultural shows. These animals are selected for rapid growth in infancy and early adolescence with exceptional development of the skeletal musculature of the trunk and limbs, which is particularly firm on palpation of the lumbar and sacral back, the wool is fine, and the animals' general conformation adheres very closely to certain special standards for their breeds. The successful stud rams retain these characteristics for several years and produce offspring of similar preferred phenotype.

I find that many of these show winners $(a)$ later manifest the disease, $(b)$ have close relatives affected by the disease or $(c)$ have affected progeny, i.e. they are $s s$ and $s S$ individuals.

Thus the breed champion ram lamb of $195^{8}$ has just developed the disease. In five flocks six outstanding stud rams developed the disease, while ro others in six of the leading flocks have affected progeny. In flock $A$ of the six affected rams, all were used until the disease manifested and four were used extensively for three to four seasons; of five other preferred rams used for 4-7 seasons, all sired affected progeny. In a moderate flock which had been free of scrapie, through the introduction of a superior outside ram, a show winner was produced, who together with a prizewinning son has died of scrapie.

The preferred female phenotypes show a similar association. In flock A, of $3^{6}$ animals shown between $194^{8}$ and $195^{8}$, I 5 have died of scrapie and 15 others had one parent affected or progeny affected. The daughters of an ss ram are often preferred for show purposes and for flock replacements even in the best flocks. Thus in a flock with a low presumptive gene frequency in the flock ewes (table 3 (ii)), into which an ss ram was introduced, of 34 of his daughters born in 1956, 53 per cent. were retained in the flock while of the remaining I 57 young females by other sires, 30.6 per cent. were retained. Of 27 sons of the ss ram, 22 were sold for breeding at an average price $7 \cdot 2$ per cent. above that made by the 89 sons, out of I I 5 born, sold for breeding by other sires.

The ram making the record price at auction between $1939-5^{8}$ has died of scrapic. 
The scrapie gene is thus associated with animals of superior commercial value, and with the phenotypes preferred by current "Show" and selection standards.

\section{(iii) Polymorphism}

The superior characteristics of the heterozygote and pure recessive scrapie genotypes ensure the dissemination of the gene and provide an example of polymorphism (Ford, 1957) of unusual type. Where selection of breeding animals has bcen based on phenotypic conformation alone, the use of scrapie phenotypes as a standard for selection will produce a state of transient polymorphism which can lead to very high gene frequencics. When this occurs the annual ewe mortality rate becomes so high ( $>$ Io per cent.), that the flock is disbanded. This has probably happened frequently in the past and indeed the decline in sheep numbers, especially of one breed, in one English county since 1940 has been determincd to a considerable extent by this situation.

In flocks in which sclection is based on performance records as well as phenotypic conformation, a state of uneasily balanced polymorphism arises duc to the operation of selection against the progeny of known affected individuals. The balance is unstable and can be seriously disturbed if, for example, a successful stud sire of ss genotype is lost from competing risks beforc manifestation. The result of this artificial situation is to produce a very unstable form of balanced polynorphism.

\section{(iv) Pleiotropic effects of the scrapie gene}

The clinical expression of lethal genes affecting the ncuromuscular system in adult life is usually varied. This is almost certainly true of scrapie, for the clinical disease in rams is often different from the classical forms so commonly seen in ewes. There are also the nonrubbing syndromes of myasthenia, palsy and wasting, seen so frequently in scrapie-affected flocks, which may well prove to be related closely to the scrapie genotypes.

\section{(v) Analogous diseases in man}

There are a group of heredo-familial "system " diseases in man which in broad outlinc exhibit many similarities to scrapie, although their modes of inheritance appear to be more involved and are often dominant. These are the progressive fatal hereditary myopathies and a taxias.

The myopathy described by Barnes (1932) in 7 generations of an English farnily mimics the special development of the skeletal musculature seen in scrapie. The myopathic members were noted for exceptional muscular development and strength in adolescence and early adult life, but they later developed various syndromes of hypertrophy and atrophy of the muscles with adiposity, usually 
between the ages of 35 and 5o. The non-myopathic members do not show this muscular development and are not adipose. Males and females were affected in equal numbers and the condition appears to be inherited as a simple dominant.

Examples of human disease due to recessive genes manifesting in adult and middle age are infrequent. One of the few is another form of muscular dystrophy, in which the limb girdles are affected but not the face (Stevenson, Cheeseman and Huth, 1954-55). The recognition of this form of inheritance presents particular difficulties, and sufficient data are only likely to arise in self-contained populations with considerable consanguinity. This is illustrated by the muscular dystrophy investigated by Minokowski and Sidler (1928) which appeared suddenly in an isolated Swiss community. Thirteen cases occurred in one generation among io families each of whose parents were descended from two separate sixteenth-century families. The disease was considered to be due to two recessive genes, which probably arose as mutations in the sixteenth century.

The high incidence of amyotropic lateral sclerosis in the Mariana Islands, especially Guam, led to the recognition that heredity might be an important cause (Kurland and Mulder, 1954). Subsequent study of the families of cases on the North American Continent revealed that it may be inherited through a single dominant gene (Kurland and Mulder, 1955).

The group of syndromes of progressive ataxia described by Schut and his collaborators (Schut, I950, I95I; Schut and Haymaker, 1951; Schut and Böök, 1953; Matson, Schut and Swanson, 196r) in 45 members of six generations of a family of Dutch ancestry with 343 individuals, illustrates the extreme pleiotropism of clinico-pathological expression which may occur in a single genetic entity. They have observed, within this one family, syndromes which conform to the criteria of Friedreich's ataxia, spinocerebellar tract degeneration, olivopontocerebellar atrophy, primary cortical cerebellar atrophy, degeneration of the dentate nucleus and brachium conjunction and hereditary spastic paraplegia. All conform to a dominant form of inheritance with complete penetrance, although there may be partial sex-linkage. The usual age of onset is 17 to 35 years with a mean of $26 \cdot 5$ years.

Kuru (Trembling) is a fatal neurological disease of certain isolated tribes in Central New Guinea (Zigas and Gajdusek, 1957; Bennett, Rhodes and Robson, 1959; Fowler and Robertson, 1959; Gajdusek and Zigas, 1961) in which certain pathological features, notably the gliosis and vacuolation of neurones (Klatzo, Gajdusek and Zigas, 1959), are also seen in scrapie. Patients with Kuru exhibit disturbances of locomotion of slow onset which eventually immobilise them; these are aggravated by effort or emotion as in scrapie and there are accompanying psychic changes in both diseases. Kuru is probably due to a dominant gene causing death in childhood in both sexes 
when homozygous, but in the heterozygote form only lethal in females when adult and after reproductive age.

Whether a transmissible agent is associated with any of these human diseases is unknown.

\section{DISCUSSION}

Scrapic is both an infective and genetic discase. Clinical manifestation is determined wholly by heredity mediatcd through the mechanism of particulate inheritance and meiosis. But the clinically affected genotype contains a potentially infective, self-replicating pathogenic particle, which does not spread naturally. Such a combination of heredity and a transmissible agent is unusual, and ccrtain possibilities arise.

The infective agent might be a natural infection of many, if not all, sheep and goats but only produce pathological damage sufficient to cause clinical signs in ss sheep, just as certain encephalogenie viruses of man highly pathogenic for most mice are harmless clinically for certain genetic strains. However, in such clinically healthy mice the virus infection can be demonstrated. In sheep TSA has only been demonstrated so far in animals with clinical signs, or in experimentally inoculated animals killed shortly before the usual time of onset of clinical signs. There is therefore as yet no evidence that natural scrapie is due to a very high susceptibility of one genotype to a naturally infectious agent; and to sustain such a postulate we should have to assume that the agent has been widespread in the sheep population of Western Europe for at least 200 years.

Certain transmissible agents require for their spread a special combination of a host of susceptible genotype and unusual environmental factors. Thus the agent of certain mammary carcinomata of mice is transmitted through the milk but is only pathogenic to certain genotypes (Bittncr, 1958), while certain mouse leukæmias are due to a virus pathogenic for certain genotypes only. Sometimes non-susceptible genotypes can be rendered susceptible by irradiation (Gross, 1959, 1961). TSA might be an agent of these kinds, but there is no evidence that it is transmitted through the milk or in the womb, and our irradiated lambs (Mole and Parry, unpublished) have survived inoculation with TSA better than their unirradiated littermates. Adequate data on inoculation of sheep of known genotype are lacking.

Many infective particles of this kind are not naturally infectious but can be transmitted artificially by inoculation. The agent which causes tumour formation in many plants infected by Phytomonas tumefaciens, or that of $\mathrm{CO}_{2}$ susceptibility in Drosophila (Darlington, 1949) behave in this way. Similar examples are the many spontaneous or induced mammalian tumours, mainly in mice, which can be transmitted in cell-free filtrates but are not naturally infectious. 
Sometimes these artificially infective agents only develop in certain genotypes. In the currant moth, Abraxas grossulariata, there is a spontaneously occurring polyhedral virus, which is invariably lethal before reproductive age, but this virus only arises in one specific genotype, the variety lacticolor, although it can be made to infect other genotypes artificially (Smith, 1952). Scrapie presents a very similar situation. Furthermore the variety lacticolor represents a balanced polymorphism of Abraxas just as scrapie represents a balanced polymorphism of sheep.

Thus scrapie combines the gene-determination of the Abraxas virus with the non-natural infectivity of a group of transmissible agents of various origins. To this group Darlington (Darlington and Mather, 1949; Darlington, 1958, 1960) has given the name "provirus", intermediate between a naturally transmissible virus and a genetic particle in the cytoplasm or plasmagene.

A simple hypothesis which embraces the facts at present known regarding scrapie might be as follows:

(1) TSA is produced in ss sheep at or shortly before the development of clinical signs of the disease. It is present in many tissues, including the cerebro-spinal fluid, although pathological damage is most evident in the central nervous system.

(2) TSA is not produced in $S S$ or $S s$ sheep.

(3) The inoculation of tissue homogenates containing TSA into some but not all sheep (their genotypes are not known precisely) is followed by the multiplication of TSA, and its appearance in the cerebro-spinal fluid.

(4) Thus a diffusible particle connected with the ss genotypes reacts with a substrate present in many sheep (and all goats) to give rise to TSA.

(5) TSA does not pass naturally from one sheep to another. In all sheep in which it is formed naturally it arrives always and entirely by heredity, never in any part or respect by infection.

(6) TSA is, therefore; not a natural virus; it is a provirus which could be a forerunner of a natural virus.

Scrapie with its dual ætiological mechanism of gene and provirus, is an example of a special category of genetic disorder mediated through a specific chemical particle and whose final expression is not due to a simple negative defect in an enzyme system. The slow accumulation of this particle is closely associated with the degeneration within the central nervous system and elsewhere, upon which the development of clinical illness primarily depends.

\section{SUMMARY}

I. Scrapie is a wasting disease of sheep, with rubbing and ataxia fatal in six weeks to one year; it has been known since $I 720$. 
2. Data are presented on I 200 affected sheep among a recorded population of 20,000 .

3. The disease may appear at any time after $1 \frac{1}{4}$ years of age up to I I years, with a mean of $3 \frac{1}{4}$ years. It occurs with variable incidence in many improved breeds of sheep. Males and females are affected equally. Seventy per cent. of a female birth-group may be affected but the attack-rate is more usually 5 to Io per cent. (figs. I and 2).

4. Ninety per cent. of all animals that will be affected manifest the disease by $4 \frac{1}{2}$ years old. This age has therefore been taken as a level for assessing the performance of all animals (table I).

5. The diseasc is due to a single autosomal recessive gene ss (tables 2 and 3 ).

6. The genetic disease is artificially infectious by inoculation, but never naturally (tables $4,5,6$ and fig. 6).

7. The scrapie gene is closely linked to certain preferred breed characteristics selected in show animals, so that ss and $S s$ sheep are at a selective advantage.

8. Scrapie is thus an example of balanced polymorphism, unconsciously favoured by current methods of selection, which allow the frequency of the gene to reach very high levels.

9. Scrapie arises by a dual mechanism of gene and provirus. The scrapie provirus is gene-determined but it lacks certain properties of a natural virus.

Io. Scrapie falls into a special category of genetic disorder, in which the physiological action of the gene is mediated by a specific particle, with independent powers of self-replication and pathogenicity.

Acknowledgments. - This work has been made possible by the generous support of the Nufficld Foundation and of the National Foundation for Ncuromuscular Diseases of New York. I would thank Dr G. S. Dawes and Professor P. M. Danicl for their help at many points, and Dr N. T. J. Bailey, Dr Alan Robertson, Dr A. C. Stevenson and Dr E. B. Ford, F.R.s., for valuable suggestions. I am particularly indebted to Dr J. A. Fraser Roberts for his advice on the original handling of the data, notably for table 3, and to Professor C. D. Darlington, F.R.s., for his advice with the final presentation. The collaboration of flock owners and shepherds, especially those connected with flocks $\mathrm{A}$ and $\mathrm{B}$, is deeply appreciated.

\section{REFERENCES}

Al.lison, A. C. 1954-55. Notes on sickle-cell polymorphism. Ann. Hum. Genet., 19, 39-51.

BARNES, s. 1932. A myopathic family: with hypertrophic, pseudo-hypertrophic. atrophic and terminal (distal in upper extremitics) stages. Brain, 55, I-46.

BECK, E., DANIEL, P. M., AND PARRY, H. B. Ig6r. Hypothalamic and cerebellar system degenerations in shecp with "scrapic". Proc. and Int. Congr. Neuropath., Munich (in press).

BENNETT, J. H., RHODES, F. A., AND ROBSON, H. N. 1959. A possible genetic basis for kuru. Amer. 7. Hum. Genel., II, I69-1 87.

BirtNer, J. J. 1958. Genetic concepts in mammary cancer in mice. Ami. N.Y. Acad. Sri., 7I, 943-975. 
BOSANQUeT, F. D., DANiel, P. M., AND PARRY, H. B. 1956. Myopathy in sheep : its relationship to scrapie and to dermatomyositis and muscular dystrophy. Lancet, ii, 737-746.

CHANDLER, R. L. 1959. Attempts to demonstrate antibodies in scrapie disease. Vet. Rec., 7I, 58-59.

COMber, T. 1772. Rickets in sheep. Critical Rev., Lond., 34, 72-73.

Cuillé, J., AND CHElle, P.-L. 1936. La maladie dite "tremblante du mouton " est-elle inoculable? C.R. Acad. Sci., Paris, 203, 1552-1554.

DARlington, c. D. 1949. Les Plasmagènes. Unités biologiques douées de continuité génétique, (1948: Coll. Cent. Nat. Rech. Sci., Paris).

DARlington, c. D. 1958. Evolution of Genetic Systems. 2nd ed. Oliver and Boyd, Edinburgh and London.

Darlington, c. D. 196o. Origin and evolution of viruses. Trans. Roy. Soc. Trop. Med. Hyg., 54, 90-96.

DARlington, c. D., AND MATHER, K. 1949. The Elements of Genetics. Allen and Unwin, London.

FORD, E. B. 1957. Polymorphism in plants, animals and man. Nature, Lond., I80, $1315-1319$.

FOWLER, M., AND ROBERTSON, E. G. 1959. Observations on Kuru. III. Pathological features in five cases. Australasian Ann. Med., 8, 16-26.

Gajdusek, D. C., AND gigas, v. 1961. Studies on kuru. I. The ethnologic setting of kuru. Amer. J. Trop. Med. Hyg., 10, 80-91.

GRoss, L. 1959. Serial cell-free passage of a radiation-activated mouse leukæmia agent. Proc. Soc. Exper. Biol. Med., roo, 102-105.

Gross, L. 1961. Oncogenic Viruses. Pergamon Press, London.

klatzo, 1., Gajdusek, D. C., AND zigas, v. 1959. Pathology of kuru. Lab. Invest., $8,799-847$.

KURLAND, L. T., AND MULdER, D. W. 1954. Epidemiologic investigations of amyotrophic lateral sclerosis. I. Preliminary report on geographic distribution, with special reference to the Mariana Islands, including clinical and pathologic observations. Neurology, 4, 355-378, 438-448.

KURLAND, L. T., AND MULDER, D. W. 1955. Epidemiologic investigations of amyotrophic lateral sclerosis. 2. Familial aggregations indicative of dominant inheritance. Part II. Neurology, 5, 249-268.

M'GoWAN, J. P. 1914. Investigations into the Disease of Sheep called Scrapie. Blackwood, Edinburgh.

MACKAY, J. M. K., SMith, W., AND STAMP, J. T. 196o. Experimental scrapie : some recent work. Vet. Rec., 72, 1002-1006.

MAtson, G. A., SCHUT, J. W., AND SWANSON, J. 1961. Hereditary ataxia : linkage studies in hereditary ataxia. Ann. Hum. Genet., Lond., 25, 7-23.

MINKOWSKI, M., AND sidLeR, A. 1928. Zur Kenntnis der dystrophia musculorum progressive und ihrer vererbung. Schweiz. Med. Wschr., 9, 1005Ioog.

Palmer, A. C. 1959. Scrapie, a review of the literature. Vet. Rev. Anot., 5, I-I5.

PARRY, H. B. 1957. Scrapie and related myopathies in sheep: preliminary observations on their investigation and attempted control by a voluntary health scheme. Vet. Rec., 69, 43-55.

PARRY, H. B. 1960. Scrapie : a transmissible hereditary disease of sheep. Nature, Lond., $185,441-443$.

PATTISON, I. H., GORDON, W. s., AND Millson, G. C. 1959. Experimental production of scrapie in goats. 7. comp. Path. Ther., 69, 300-312.

PATTISON, I. H., AND MILlson, G. C. 196o. Further observations on the experimental production of scrapie in goats and sheep. $\mathcal{J}$. comp. Path. Ther., 7o, 182-193.

SCHUT, J. W. 1950. Hereditary ataxia : clinical study through six generations. Arch. Neurol. Psychiat., 63, 535-568. 
schut, J. W. 1951. Hereditary ataxia : a survey of certain clinical, pathologic and genetic features with linkage data on five additional hereditary factors. Amer. F. Hum. Genet., 3, 93-1 10.

schut, J. W., AND Böök, J. A. 1953. Hereditary ataxia : difference between progeny of male and female affected members and a definition of certain signs useful in detecting the disease prior to onset of clinical symptoms. Arch. Neurol. Psychiat., 70, 169-1 79 .

SCHUT, J. W., AND HAYMAKeR, w. 195 I. Hereditary ataxia : a pathologic study of five cases of common ancestry. 7. Neuropath. clin. Neurol., $1,183-213$.

SMiтH, K. M. 1952. Latency in viruses and the production of new virus diseases. Biol. Rev., 27, 347-357.

STAMP, J. T., BROTHERSTON, J. G., ZLOTNIK, I., MACKAY, J. M. K., AND SMITH, W. I 959. Further studies on scrapie. J. comp. Path. Ther., 69, 268-28o.

STevenson, A. C., CheEseman, E. A., AND huth, M. c. 1954-55. Muscular dystrophy. in Northern Ireland. III. Linkage data with particular reference to autosomal limb girdle muscular dystrophy. Ann. Hum. Genet., 19, 165-1 73.

zigAS, V., AND GAJDUSEK, D. c. 1957. Kuru: Clinical study of a new syndrome resembling paralysis agitans in natives of the Eastern Highlands of Australian New Guinea. Med. J. Australia., 2, 745-754. 